глави 29 КПК України (до внесених змін від «04» жовтня 2019 року у ст. 369 КПК України).

Варто наголосити, що безпосереднє врахування фактів, що рішення приймається особою, яка перебуває на посаді судді; що рішення приймається у судовому засіданні; та що рішення приймається у будівлі суду, не можуть автоматично надавати ухвалам слідчого судді статуту «судового рішення» у кримінальному провадженні.

Таким чином, враховуючи усе вищенаведене, можна стверджувати, що обраний законодавцем шлях вирішення проблемних питань щодо правового регулювання ухвал слідчого судді у кримінальному провадженні не відповідає правовій природі інституту судових рішень. Як видається, нагальним питанням є необхідність передбачити у КПК України окрему главу, яка була б присвячена питанням правового регулювання виконання, роз'яснення, внесення змін до ухвал слідчого судді, 3 врахуванням особливостей правового статуту слідчого судді у кримінальному провадженні та покладений на нього функцій.

\title{
Література:
}

1. Кримінальний процесуальний кодекс України: прийнятий 13 квітня 2012 року № 4651-VI. Відомості Верховної Ради України. 2013. № $9-10$, № 11 - 12, № 13. - Ст. 88. http://zakon0.rada.gov.ua/laws/show/ 4651-17

DOI https://doi.org/10.30525/978-9934-26-074-2-71

\section{ВИКОРИСТАННЯ ЗНАНЬ КРИМІНАЛІСТИКИ У ДІЯЛЬНОСТІ ОРГАНІВ ДОСУДОВОГО РОЗСЛІДУВАННЯ І ДІЗНАННЯ У ПРОТИДІЇ ЗЛОЧИННОСТІ}

\author{
Юхно О. О. \\ доктор юридичних наук, професор, \\ завідувач кафедри кримінального прочесу \\ та організачії досудового слідства \\ Харківського національного університету внутрішніх справ \\ м. Харків, Україна
}

Протидія злочинності складається із системи та комплексного впливу на злочинність та окремі ії чинники. Так, А. А. Майоров, визначає, що способи реагування на злочинність можна представити у вигляді системи 
протидії злочинності, яка включає в себе заходи профілактичного i попереджувального впливу, як на окремі види злочинів, так i на злочинність в цілому. Вона має включати в себе засоби, способи i прийоми, що застосовують не тільки правоохоронні органи, але й органи місцевого самоврядування, громадські та інші організації, а також самі громадяни. Очікуваний результат протидії злочинності може бути досягнуто тільки на основі використання широкого комплексу загальносоціальних і спеціальних заходів попередження, [1, с. 57]. Криміналістика $є$ наукою про судові докази і вона є діалектикою кримінального процесу, це процедура в динаміці, передбачає використання творчого підходу, ситуаційної зумовленості, наявності альтернативи в обранні певних шляхів, методів, прийомів, методик, є самостійною галуззю наукового знання, яка допомагає встановити істину, проникнути

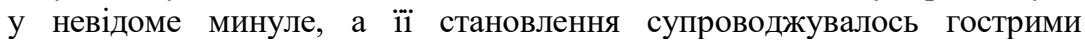
дискусіями. У сучасному стані $\epsilon$ наукові позиції відносно предмету криміналістики, зокрема, що це : 1) наука про розслідування злочинів і проступків; 2) наука про сукупність технічних засобів, тактичних прийомів та методичних рекомендацій. Всі вищезазначені позиції звужують реальний предмет криміналістики і закономірності, які вона вивчає, але підкреслюють іiі забезпечувальний характер. Вказане поняття враховувало основний зміст предмету криміналістики. Криміналістика розглядає «двоєдиний» об’єкт пізнання, зокрема : злочинну діяльність (злочинну поведінку), діяльність з розкриття і розслідування та встановлення істини у кримінальному провадженні. Панівним визначенням слід вважати наукову позицію В.Ю. Шепітька, що криміналістика це нука про закономірності злочинної діяльності та іï відображення в джерелах інформації, що слугують основою для розроблення засобів, прийомів i методів збирання, дослідження, оцінки та використання доказів з метою розкриття, розслідування, судового розгляду та попередження злочинів [2, с. 7-8]. Теоретичні напрями криміналістики потребують свого переосмислення 3 урахуванням реформування правоохоронних органів, експертних установ, появи 3 липня 2020 року нових учасників кримінального провадження - дізнавача, керівника органу дізнання та ін. i напрацювання iї нових концепцій. Розвиток криміналістики характеризується формуванням загальної та окремих теорій, розробкою i запровадженням сучасних науково-технічних розробок, засобів зв'язку, телекомунікаційних та інших інформаційних мереж i технологій, що пов'язано 3 удосконаленням прийомів криміналістичної тактики та розробкою сучасних методик їх розслідування. Накопичення нових знань на історичних етапах призводить до змін наукової парадигми криміналістики, зокрема зміни систем пануючих ідей. Вона удосконалюється в динаміці, змінюються іiі межі, сфери впливу, 
запроваджуються нові напрями та пропонуються нові теорії. Одним із напрямів криміналістичного забезпечення $є$ запровадження сучасних інновацій. Їх запровадження зумовлено вирішенням значної кількості задач у розумні, але обмежені строки; браком технічних засобів, що $є$ на озброєнні слідчих; наявними проблемами у координації та взаємодії $з$ спеціалістами різних галузей знань та оперативними працівниками; дефіцитом інформації про розслідувану подію в минулому; обмеженність джерел отримання інформації; протидією розслідуванню зі сторони зацікавлених осіб. Цей напрям сприяє підвищенню ефективності розслідування, неуможливленню помилок і може здійснюватись в наступних заходах: а) розробці та запровадженні у практичну діяльність новітніх науково-технічних засобів з метою виявлення, збирання, фіксування та оцінювання і попереднього дослідження доказів; б) опрацювання пропозицій щодо впровадження нових телекомунікаційних та інших інформаційних технологій в діяльності слідчого, дізнавача, прокурора; в) розроблення нових прийомів, тактики, методик проведення окремих слідчих (розшукових) дій та розслідування у цілому. За визначенням В. Гончаренка розвиток криміналістики постійно характеризувався залученням, удосконаленням або пристосуванням для своїх потреб досягнень природничих і технічних наук [3, с. 75-76]. Криміналістична техніка $\epsilon$ розділом криміналістики, який виник внаслідок запровадження досягнень природничих і технічних наук для виявлення слідів злочинів та отримання іншої криміналістично необхідної інформації. Розширення переліку науково-технічних засобів, що використовуються у цьому напрямі при дотриманні кримінального процесуального механізму, виносить питання про доцільність перевірки їх науковості, заборону використання антинаукових прийомів, та тих що не відповідають принципу доктринальності криміналістики і процесу. Для того, щоб науково-технічні засоби при розслідуванні злочинів сприяли підвищенню ефективності розслідування пропонується більш широко застосовувати допомогу спеціалістів. В КПК України введено новели : ст. 71 «Спеціаліст» і ст. 72 «Відповідальність спеціаліста» [4]. У районних відділах поліції та при регілональних слідчих управліннях згідно наказу Голови Національної поліції України від 24.12.2020 року «Про організаційно-штатні зміни» посади «інспекторів-криміналістів» перейменовано на «спеціалістів-криміналістів», завдання яких $\epsilon$ надання допомоги слідчим при проведенні оглядів місць події злочинів, при проведенні окремих слідчих (розшукових) дій та ін. Найбільш важливим досягненням XX століття в даній сфері є розроблення і впровадження методів ДНК-аналізу для проведення судових експертиз, а також з метою збирання, дослідження, оцінки та використання орієнтуючої та доказової інформації у кримінальному процесі. У криміналістиці раніше не 270 
приділялось належної уваги питанням ДНК (молекулярно-генетичним дослідженням), що сприяла відсутність таких методик та навчальнометодичної літератури. Не було здійснено і єдиного підходу щодо визначення місця молекулярно-генетичного аналізу в судовій експертизі, тому наразі паралельно розвиваються у криміналістичний i судовомедичний науках аспекти цієї проблематики. В Україні молекулярногенетичні експертизи почали проводити у 1988 році експертом П. Івановим у справі розумово відсталого бродяждки Сопова, якого було викрито у згвалтуванні та вбивстві двох літніх жінок [5]. Разом з тим, за визначення Степанюка Р.Л., Перліна С.I., Кікінчука В.В. у слідчий діяльності молекулярно-генетичні дослідження 3 кожним роком відіграють все більшу роль у протидії тяжким злочинам проти життя та здоров'я громадян, проти статевої свободи і статевої недоторканності, проти власності та ін. В умовах військових дій на сході України та збільшення терористичних загроз вагоме значення має застосування можливостей таких досліджень 3 метою встановлення особистості невпізнаних і обгорілих трупів і їх частин та ін. Методи ДНК-аналізу ефективно використовуються у цивільному судочинстві при вирішенні справ про встановлення батьківства, визначення біологічної спорідненості людей у випадках виявлення бездомних дітей та неповнолітніх, осіб які втратили пам'ять та ін. і таким чином, судова молекулярна генетика, по суті є міждисциплінарною сферою наукових знань, досягнення якої активно використовується в криміналістиці і судовій медицині. Її криміналістичне значення є особливо важливим, оскільки ідентифікація особи за їі генетичними ознаками відноситься до числа найбільш точних методів ототожнення людини. Генотипоскопія як розділ криміналістичної техніки має зайняти гідне місце у структурі криміналістичної науки, а відповідні положення стати частиною фахової підготовки юристів, зокрема майбутніх слідчих, прокурорів, адвокатів і суддів [6, с. 7-8]. Актуальним напрямом удосконалення діяльності слідства $є$ його комп'ютерізація, тому, що вона не може працювати без створення інтегрованих баз даних, зокрема криміналістичних, а також інформаційних систем, які можуть в багато разів спростити пошук, аналіз, передання та оброблення інформації. Слідчі та експертні установи використовують різні інформаційні системи. Сталися суттєві зміни у визначенні предмету криміналістичної тактики, а їі розвиток характеризується нерівномірністю розвитку, гіперболізацією окремих ії частин і напрямів. В минулі часи була тенденція до вивчення тактики злочинної діяльності, вивчення особи і типу злочинця, пізніше набув напрям слідчої тактики та напрацювання прийомів слідчої діяльності. Криміналістичне забезпечення діяльності сліства складається із напрацювання і впровадження систем тактичних прийомів проведення окремих слідчих (розшукових) 
дій, їх систем у вигляді оперативних комбінацій, тактичних операцій та ін. За визначенням В.Ю. Шепітька сучасний стан криміналістичної теорії дає змогу поставити питання щодо необхідності розроблення і застосування систем тактичних прийомів, які виступають оптимальним засобом виявлення доказової інформації та ії використання у судово-слідчій практиці [2, с. 112]. Так, І.М. Комаров зазначив, що проанкетовані працівники слідства заявили що у 75,5\% випадках застосовують криміналістичні операції та вказали на таку необхідність при розслідуванні злочинів. Згідно нашого анкетування 89\% працівників слідства поліції вказали про таку практику та 93,7\% працівників Державного бюро рослідування. Синтезуюче значення та значну роль виконує криміналістична методика, що поєднує рекомендації криміналістичної техніки та тактики які допомагають розслідуванню окремих видів злочинів. Вони $\epsilon$ частиною криміналістики в якій розглядаються методи і засоби, що використовуються при розкритті та розслідуванні окремих видів та груп злочинів на підставі криміналістичної характеристики і типових слідчих ситуацій [7, с. 33-39]. В. Журавель зазначає, що криміналістична методика як система знань і самостійний розділ криміналістики має вдосконалюватись через узагальнення та теоретичне пояснення накопиченого емпіричного матеріалу і пізнання наукових фактів, що належать до сфери вчинення, розкриття та попередження кримінальних правопорушень ..., доцільно викладати методичні рекомендації у найбільш доступній для сприйняття формі, в тому числі у вигляді певних алгоритмічних схем, що реалізуються на базі сучасних комп'ютерних технологій. [8, с. 177-178]. Таким чином криміналістичне забезпечення роботи слідчого у протидії злочинності можна класифікувати за такими напрямами : техніко-криміналістичний - за рахунок запровадження i розроблення нових науково-технічних засобів, техніко-криміналістичних прийомів, телекомунікаційних та інших сучасних інформаційних технологій; організаційно-тактичний - за рахунок напрацювання відповідної тактики досудового розслідування і слідчих дій при запровадженні новітніх тактичних прийомів і алгоритмів та їх систем, використання при цьому тактичних операцій і оперативних комбінацій; методичний формування i запровадження окремих криміналістичних методик. Системне криміналістичне забезпечення досудового розслідування, яке проводиться слідчим і дізнавачем, сприяє удосконаленню розкриття i розслідування кримінальних правопорушень, здійсненню протидії злочинам відповідно до наукових пропозицій і рекомендацій з організації їх службової діяльності. Втім, підняті питання не $є$ остаточними та підлягають окремому дослідженню. 


\section{Література:}

1. Майоров А. В. Виктимологическая модель противодействия преступности : монография. Москва : Юр-литинформ. 2014. 224 с.

2. Шепітько В.Ю. Криміналістична тактика (системно-структурний аналіз) : монографія. Харків. Харків юрид. 2007. С. 7-8; 112.

3. Гончаренко В.И. Использование данных естественных и технических наук в уголовном производстве (Методологические вопросы) : монография. Киев. Вища школа. 1980. С. 75-76.

4. Кримінальний процесуальний кодекс України: станом на 18 вересня 2020 р. Харків. Право. 428 с.

5. Мостовщиков Е. Профессор на тропе войны. Русский репортер. № 4 (342). 10.04. 2014.

6. Степанюк Р.Л., Перлін С.І., Кікінчук В.В. Криміналістичне дослідження ДНК : технології та можливості: навчальний посібник. Харків. ФОП Панов А.М. 2019. 144 с.

7. Герасимов И.Ф. Общие положения методики расследования преступлений. Криминалистика : учебник. Под ред. И.Ф. Герасимова, Л.Я. Драпкина. Москва. Высшая школа. 1994. С. 325.

8. Журавель В.А. Сучасні концеції формування окремих криміналістичних методик розслідування злочинів. Вісник Академії правових наук України. 2007. Вип. 2(49). С. 177-184. 